Georgetown University Law Center

Scholarship @ GEORGETOWN LAW

1983

\title{
Contemporary Social Historical Perspectives on Mental Health Reform
}

Lawrence O. Gostin

Georgetown University Law Center, gostin@law.georgetown.edu

This paper can be downloaded free of charge from:

https://scholarship.law.georgetown.edu/facpub/767

10 J.L. \& Soc'y $47-70$ (1983)

This open-access article is brought to you by the Georgetown Law Library. Posted with permission of the author. Follow this and additional works at: https://scholarship.law.georgetown.edu/facpub

Part of the Health Law and Policy Commons, Health Policy Commons, and the Law and Psychology Commons 
IOURNAL OF LAW \& SOCIETY

VOLUMe I0, Number I, SUMmer 1983

\section{Contemporary Social Historical Perspectives on Mental Health Reform}

\section{LARRY GOSTIN*}

Social historians have sometimes characterised the process of reform of mental health legislation as a pendulum swinging between two opposing schools of thought - legalism and professional discretion.[1] Neither term is susceptible to neat definition. Traditional "legalism" appears to embody a set of principles whereby the use of compulsory powers in mental health should be carefully limited by clear criteria and legal procedures; often the term is used to signify the importance of a judicial determination of the need for compulsory admission. The Lunacy Laws, 1890-1930 contained intricate legal regulation of admission to, and conditions in, hospital. This legislation, devised in the social ostracism of the late Victorian era, was seen in conventional social historical assessments as an obstacle to early and effective treatment of mentally disordered people.[2] The Mental Health Act 1959 was thought of as a negation of, and reaction to, legal formalism. Its approach was effectively to make access to treatment and care a matter for professional discretion. Review of medical decisionmaking was limited to a small minority of cases; the system of review was to be de facto and exercised by an administrative tribunal with a medical component.[3]

The Mental Health (Amendment) Act 1982 will be seen as a swing towards legal formalism. Its main provisions are concerned, principally, with furthering the legal safeguards available to patients, although it does not go so far as to remove from professional discretion the initial decision in respect of admission and treatment. This article is written from the perspective of someone who has been identified as having sought to influence the Parliamentary process on mental health reform toward a "new legalism".[4] Since, on a conventional view, this is seen to be following an historically discredited path, the article will examine some of the main arguments against the legal approach; explain the legal strategy which underlay the effort to reform the 1959 Act; and critically review the main provisions of the 1982 Act.

\section{THE MODERN FUNCTION OF LAW IN RELATION TO PSYCHIATRY}

The tension between "legalism" and "professional discretion" is probably the central cause of controversy at the interface of psychiatry and law. [5] In

"Legal Director MIND (National Association for Mental Health); Visiting Fellow, Oxford University, Centre for Criminological Research. 
psychiatry, there is the perception that the legal profession is seeking to substitute its discretion for that of the medical and social work professions. It should be observed that there is little in the traditions, training or experience of judges or members of the legal profession to commend them in preference to mental health professionals who are traditionally associated with humanitarian values. Professor Kathleen Jones suggests that legal intervention can only be remedial, not creative or inspiring: "The need is not for increased legal formalism, but for human compassion and professional skill ... Legal enactments have been tried repeatedly and contributed little to genuine psychiatric progress".[6]

Professor Jones' argument is directed against a legal formalism that few would support. Contemporary legal philosophy goes beyond the technical formalism associated with the Lunacy Laws. It does not seek to erect a cumbersome legal framework or to introduce technical legal procedures. Thus, the argument that the "new legalism" is treading an historically discredited path does not take account of contemporary legal thought, although it is fair to react cautiously to any proposal which relies entirely upon legal or judicial decision-making. It is also improper to suggest that law and humanism are mutually exclusive - that there exists a sterile choice between "legal enactments and restrictions" or "genuine psychiatric advance", but not both.

Traditional legalism is founded upon the application of a body of law to individual cases so that relatively consistent and fixed results accrue from reasonably equivalent factual circumstances. Such attempts to promote consistency and reasonable objectivity in psychiatric decision-making are, in principle, sound. However, those who oppose legal intervention argue that a formalistic or mechanistic approach is not suited to a field of human endeavour which is, by its nature, individualistic and unpredictable; while "remedial law" can lay down relatively fixed and simplistic rules to penalise illegal activity, it cannot formulate a logical regulatory framework for complex issues relating to human behaviour. It is true that the law has not succeeded in trying to prescribe in detail the circumstances in which compulsory psychiatric intervention is justified; there is perhaps no other body of law which has undergone as many fundamental changes in approach and philosophy as mental health law. Nevertheless, where decisions involve the removal of a person's liberty or some other right of self-determination, it is no answer to say that the law should not control this activity because there are no reliable and consistent factors which could govern such decisions. If this were the case, the remedy would not be to leave medical discretion unfettered; rather, it would suggest that the discretion should not be exercised at all, and certainly not under the authority of law.

The most compelling argument against the traditional legal approach to psychiatry is that it is essentially negative and reactive; the law reacts to events and attempts to control them once they have occurred, but it cannot 
shape or influence them in a positive way. The law can examine narrow issues such as the occasional misuse of medical authority or the technical unlawfulness of admission. It can even regulate in some detail the provision of mental health services by setting boundaries and monitoring professional practice. However, it cannot effectively examine and resolve the more fundamental mental health issues relating to providing services and meeting needs, particularly in community-based settings. Creative ideas relating to the provision of services for people suffering from mental distress seldom emanate from the legal profession. Moreover, the law appears incapable of contributing to the development of effective services as this requires long-term planning, budgeting, building, and management. Clearly, these aspects of effective service provision are not within the competency of the courts or the law. Nor do members of the legal profession have the experience or expertise in areas of health and social services to enable them to identify needs and to propose workable solutions.

In sum, the legal approach to psychiatry has traditionally and perhaps necessarily been narrow and predictable. It has become an almost routinised and highly reactive counterbalance to medical and other professional authority. It has therefore virtually lost any identity of its own, save as being regulatory and critical of established psychiatric interests in a most predictable way.[7]

The argument presented here is that a new role has been developing in law which can and should be used as a strategy in the provision of services. It would be quite wrong for the reasons given above to consider the law as the exclusive or the most important element in the provision of medical and social services. Yet a distinctive role can be identified. It will be further argued that there is an important place for the law in setting limits on established psychiatric measures relating, for example, to compulsory admission and treatment, and even to particularly hazardous measures taken with the consent of the patient. The final role of law is to ensure the civil status of those who are the consumers of psychiatric services. One must accept the fact that pernicious legal and social consequences sometimes are secondary features of the receipt of psychiatric services. Here the law can make a distinctive contribution to uphold a person's personal status and dignity. This approach does not pretend to offer a solution to the more collective problems relating to deficiency in services, but the more individualistic approach of the law has its own legitimacy in upholding the integrity of people who have felt dehumanised by institutions, by the opprobrium of society and by the discriminatory character of legislation.

THE IDEOLOGY OF ENTITLEMENT: THE CONTRIBUTION OF LAW TO THE PROVISION OF ADEQUATE HEALTH AND SOCIAL SERVICES

The premise of the ideology of entitlement is that access to health and 
social services should not be based upon charitable or professional discretion, but upon enforceable rights. The rules of equity and fairness are deeply entrenched principles of law. From a broad legal perspective, a government is not obliged to provide health and social services. However, once it chooses to provide services, it cannot arbitrarily deprive or exclude certain individuals or client groups. If there is an unreasonable denial of a service, the remedy is, or should be, provided by the law.

The right to a service, of course, does not emanate from intangible jurisprudential or moral philosophy, but from statute, administrative regulation or common law. Great Britain, for example, provides a reasonably comprehensive health and social service. There is a wide ranging body of legislation which provides a general entitlement to treatment, care, housing, social and legal services.[8] Thus, the provision of services is, from its origin, integrally associated with law. Improvements in the nature or quality of that service lie, at least in part, on enforcement of the law or in its reform. This approach relies, in part, upon "open textured" or "enabling" legislation which must be supported by adequate financing, efficient management and good practice. Schedule 8(2) of the National Health Service Act 1977, in conjunction with DHSS Ciruclar 19/74, provides a general entitlement to community-based social services for mentally disordered people.[9] The availability and adequacy of such services are important because they can either prevent the need for compulsory hospital care or can shorten its duration. This upholds the principle of the "least restrictive alternative" - i.e. the use of compulsory - powers must be the least invasive of individual liberty and autonomy as is necessary for the achievement of valid public objectives. Thus, if equally effective treatment and care can be achieved in a community setting and without the use of compulsory powers, that alternative should be pursued in preference to confinement in hospital. The principle of the least restrictive alternative would require the Government to create a full range of community services including housing, crisis intervention, medical and nursing support, training and employment. It would require the social worker to explore community alternatives before making an application for admission to hospital, and to refuse to make an application where the person could be supported at home or in a non-institutional setting.

One way to achieve the objective of community-based health and social services is to place specific statutory duties on health and local authorities. The ideology of entitlement, then, can seek to establish the right to a service which can be enforced at the behest of a client group or an individual. This draws the attention of the relevant public authorities to their legal and social obligations to particularly under-privileged client groups and draws public attention to under-provision and under-resourcing in areas of concern. There is an expectation that this legal approach will be resisted because public authorities and professionals wish to allocate scarce resources at their discretion and not in accordance with the principle of 
entitlement. The consumers of psychiatric services are not an organised political force. The ideology of entitlement represents one method of creating pressure for access to services, as well as a more equitable distribution of services, to an extremely vulnerable group.

Important instances in the Mental Health (Amendment) Act 1982 of the concept of "entitlement" to services involve after-care and crisis intervention services - which are both community-based and emphasise the avoidance of hospital care. A further example of service entitlement is in the provision of publicly-funded legal representation for patients. Unsurprisingly, none of these reforms were in the Bill as originally published and each was resisted by central and local Government during the Parliamentary process.[10]

\section{After-Care Services}

Section 51 of the Amendment Act lays a duty on the District Health Authority and the local social services authority, in co-operation with relevant voluntary agencies, to provide after-care services. The section applies to persons, having been detained for treatment or under a hospital order or transfer direction, who cease to be detained and leave hospital. "After-care services" are not defined in the Act but the duty remains in force until the District Health Authority and social services authority are satisfied that the person no longer needs such services. The authority which has the mandatory duty is the one in which the person concerned is resident or to which he is sent upon discharge.

The Parliamentary debates relating to the amendment repeatedly emphasised the chronic under-provision of after-care facilities; the fact that after-care would prevent prolonged institutionalisation of mentally disordered people in hospitals and prisons which would be both invasive of individual liberty and uneconomic; and that a specific and unequivocal mandatory responsibility placed in mental health legislation would encourage public authorities to make after-care for detained patients a priority.[11]

Baroness Masham of Ilton, who moved the amendment, said its purpose was "to restate what should be in the statute. The present legislation dealing with after-care for problem patients is unconsolidated and nonobligatory."[12] Lord Redcliffe-Maud, during the Third Reading debate in the House of Lords, where the amendment was first carried, made perhaps the clearest enunciation of the principle of entitlement:

I know there is power in both the local authority and in the National Health Service to see that what we all want to happen does happen, but . . . with local authorities so cut back and restricted in their ability to raise money for proposals more politically viable than the health of the mentally defective and mentally ill, they are not going to do what is wanted unless there is a very clear instruction from Parliament . . . [13]

The after-care amendment was discouraged by central Government and by 
local authority representatives throughout its passage in Parliament.[14] Its weaknesses are that it applies only to long-term compulsorily detained patients; it is not sufficiently detailed in setting out what an adequate aftercare service would comprise; and it does not provide any clear methods of enforcement. More importantly, the amendment was not thought to have substantial revenue implications which indicates that, if it is to be implemented at all, the funding must come from other areas of the health and social services budget.

\section{The Role of the Approved Social Worker}

There are two general aspects of the decision to exercise compulsory powers under mental health legislation. The first involves a medical assessment: whether the person is suffering from mental disorder; whether admission to hospital is necessary for his own health or safety or for the protection of others; and whether the treatment will ameliorate the person's condition. Prior to the Amendment Act, Parliament had not provided any guidance as to the second aspect of the use of compulsion i.e. the social assessment. The Mental Health Act 1959 did not specify minimum standards for the appointment of Mental Welfare Officers (MWOs); the Act showed a preference for applications by relatives, thereby circumventing the need for an expert social assessment; and there were no clear criteria for the exercise of social work judgments.

The Amendment Act places three new responsibilities on local social services authorities and MWOs. First, before making an application for -admission, an MWO must interview the patient and satisfy himself that "detention in hospital . . . is the most appropriate way of providing the care and medical treatment of which the patient stands in need" (s.16(3)). Second, a duty is placed on a local social services authority, if so required by the nearest relative or a patient residing in their area, to direct an MWO to consider whether an application ought to be made. If the MWO decides not to make the application, he must inform the nearest relative of his reasons in writing (s.16(3)). Third, where a patient is admitted under an application for assessment or treatment made by his nearest relative, the hospital managers must give notice of this fact to the local social services authority for the area in which the patient resided, and that authority must arrange for a social worker to interview the patient and provide the managers with a report on his social circumstances (s.17).

These three provisions, taken together, show a recognition of the importance of a social assessment either prior to, or shortly following, the exercise of compulsory powers. The social work role is to examine community alternatives to compulsory admission to hospital. The social worker should examine, not whether medical treatment in hospital is warranted, but whether, in view of the alternative services and support that could be provided in the community, admission is the most appropriate way of providing that treatment. 
The Amendment Act also reflects the recognition that MWOs require appropriate training and experience. Accordingly, two years after the passage of the Act (October 28, 1984) the functions conferred on MWOs will be discharged by approved social workers. Approved social workers must be appointed by the local social services authority as having appropriate competence in dealing with persons who are suffering from mental disorder (s.61).

\section{Towards More Radical Reform}

There were significant, albeit unsuccessful, attempts in the Parliamentary debates preceding the 1982 Act to pass far reaching amendments entitling mentally disordered people to have a legal entitlement to crisis intervention and broad community-based services. The essence of crisis intervention services is that, through the availability of a 24-hour multidisciplinary team, emergency mental health problems can often be resolved in the community without resorting to compulsory hospital admission.[15] The previous Government accepted this concept in its 1978 White Paper and suggested that an emergency application under section 29 of the 1959 Act "should allow a person's removal to a "place of assessment" and that this should be defined to include any local authority social services or health authority accommodation, as well as a hospital".[16] The use of legislation to correct under-resourcing was a persistent theme of the Opposition who also attempted to extend the Masham amendment to apply to all persons suffering from mental disorder, as a measure of prevention, care and after-care.[17]

Future mental health legislation should extend the concept of a full entitlement to a wide range of "less restrictive" and more effective community-based services. There is also a case for moving towards a right to treatment for in-patients. The rationale for a "right to treatment" is particularly persuasive in the case of compulsorily detained patients. Compulsory admission to hospital is justified, in large part, by the person's need for treatment, together with his failure to comprehend the existence of such a need. Equally important, confinement should cease when the reasons for the use of compulsion no longer exist.

An "admission for treatment" necessarily implies that the purpose of admission is treatment, and its goal is to restore the person to a position of health and social stability where he can return to the community. The confinement should continually be justified by progress towards the goal set at the time of admission. The state could rationally justify continued detention of a person only if adequate treatment were available. From the perspective of the exercise of state authority, then, the duty to provide treatment is the corollary of the right to exercise compulsory powers.

\section{Legal Services}

In addition to the theme of a legal entitlement to health and social services, 
a persistent feature of the Parliamentary debates involved an ultimately successful attempt to provide patients appearing before Mental Health Review Tribunals with an entitlement to public funding for their legal representation. The effectiveness of Mental Health Review Tribunals is only to a limited extent dependent upon their procedures and powers. Far more important is the availability and quality of representation. The effects of institutionalisation, the patient's mental illness or handicap, his deference to medical authority and the effects of major tranquillisers, make self advocacy invariably difficult and sometimes impossible. Further, the unrepresented patient is frequently denied the full details of the case against him, including medical and social enquiry reports, which provide the rationale for detention. [18]

One of the central criticisms of the legal formalism of the old Lunacy Laws was that the review by a magistrate presented formal procedural barriers to access to care, but was not a reliable safeguard against medical discretion exercised without sufficient cause or justification; magistrates' review became a highly routinised confirmation of medical authority.[19] The new legalism does not seek formalistic (but essentially ineffective) review procedures. Rather, it seeks to ensure a full and fair hearing of the case relating to the use of compulsory powers without recourse to unnecessary formality. A trained representative is needed to put the legal, medical and social aspects of the case to the tribunal. The availability of representation, moreover, should not be a matter which is dependent upon the ability of the patient to pay. Mental Health Review Tribunals are the - only tribunals where the outcome of the hearing affects a person's liberty. It is very much a part of the legal approach in mental health to ensure that there is public financing for representation to enable the patient to know and critically examine the reasons for detention, to seek independent professional advice and to explore community alternatives to hospital care.

The arguments in Parliament for the right to state-aided representation were advanced primarily by lawyers who emphasised the importance of effective legal controls on matters involving individual liberty.[20] Concurrently, there was public pressure placed on the Government from the Law Society and Lord Chancellor's Advisory Committee to extend Assistance by Way of Representation (ABWR) for representation before Mental Health Review Tribunals. [21] MIND lodged an application, Collins v. the United Kingdom, with the European Commission of Human Rights alleging that Article 5(4) of the Convention required Contracting Parties to grant public financing to their nationals for representation at mental health hearings.[22] The Collins application is awaiting a decision of the Commission. It should be observed, however, that the organs of the Convention have repeatedly emphasised the need for effective legal assistance as part of the "special procedural guarantees" required in mental health cases.[23] Further, in Airey v. Republic of Ireland, the Court considered that the right of a person to appear in the High Court without represen- 
tation would not be "effective in the sense of whether she was able to present her case properly and satisfactorily". The Court concluded that publicly funded representation was required so that her rights under the Convention were not "theoretical or illusory", but "practical and effective".[24]

The Government twice resisted amendments in the House of Lords to extend ABWR to Mental Health Review Tribunals, but only by narrow margins.[25] The House of Commons Committee Stage was preceded by an unusual Special Standing Committee which invited the Lord Chancellor's Department and others to give evidence. A memorandum on behalf of the Lord Chancellor to the Special Standing Committee stated that the "Government has now decided that ABWR should be made available for representation before Mental Health Review Tribunals".[26] The Lord Chancellor subsequently brought forward the necessary regulations under section 2A(3) of the Legal Aid Act 1974. [27] Further, the Lord Chancellor's memorandum acknowledged the criteria for ABWR would be framed so that there would "rarely, if ever, be circumstances in which this type of assistance would be refused to a patient".[28]

\section{LIMITATIONS ON THE PRACTICE OF PSYCHIATRY}

The decision to delegate wide discretionary authority to the medical profession under the 1959 Act was made at a time of general optimism about the capacity of the medical profession to solve society's age-long problem of disease and deviance. In particular, medicine was perceived as making great advances in the search for the aetiology and treatment of schizophrenia; this was the time of the discovery of the major tranquillisers and it was to be the beginning of an era where patients were to leave institutions to be cared for in the community. It was within this social context that medicine was perceived as manifestly humane, whereas the law was seen as subordinating the individual's welfare to the collective good.[29]

When one looks at psychiatry in this historical context and acknowledges its deep affinity with humanism, it is curious that today it is associated, perhaps more than any other profession, with power and its abuse. The science of psychiatry has not fulfilled the unrealistically high expectations that prevailed in the late 1950 s. There is still substantial disagreement concerning the causes of mental illness and no clear understanding of why many treatments are thought to have a therapeutic effect. The 1959 Act was founded upon the benefit that was thought to accrue to the patient. The assumption was that psychiatrists could reliably and validly diagnose particular forms of mental disorder, that they have an ability to predict future behaviour in cases where the layman could not and that treatments with established benefits exist. Yet, the evidence to demonstrate the scientific objectivity of psychiatry is today highly equivocal.[30] 
There is a sense of contradiction in the way that contemporary psychiatry presents itself. Psychiatry purports to be a specialism of medicine; it strives toward objectivity and identifies with the natural sciences. The psychiatric journals bristle with research to seek to establish the empirical efficacy of somatic treatments. At the same time, psychiatry asks not to be held to account for its views in an objective and scientific way. It asks, rather, to operate under the ambiguous parameters of "clinical judgment", which relies not upon an empiricist view but upon unspoken areas of personal intuition and subjective judgments.

The objective of the legal approach is to ensure, particularly where compulsion is involved, that the psychiatric experts, minimally, can explain and justify their decision to the lay person and that there exists some objective behavioural evidence. Psychiatric decisions have been based upon "expert" opinion and, predictably, doctors have insisted upon their expertise. In this way they have avoided a wider review of their decisions. Mental health professionals, according to the legal approach, should be required to state the grounds for their decisions in terms which are open to examination by others. The confrontation should then be on the question of the adequacy of the grounds advanced and not on the basis of presumed expertise. This is the area of disagreement at the interface of law and psychiatry. The legal approach does not accept unsupported claims of knowledge in areas of diagnosis, behaviour prediction, or treatment. In each context the law should require some observable evidence to support professional judgments.

The Mental Health (Amendment) Act 1982 did not remove from psychiatrists, social workers and others the right to exercise professional judgment, nor were clear legal boundaries (substantive criteria and procedures) set at each stage in the decision-making process. Undoubtedly, however, the trend was toward more precise definitions and more frequent opportunities for review of professional judgments relating to the classification of mental disorder, compulsory admission and treatment.

\section{Classification of Mental Disorder}

The Amendment Act reduced professional discretion to recommend the compulsory admission of patients in several significant ways. The definition of mental disorder was unchanged, except that a person may not be classified as mentally disordered by reason only of "promiscuity or other immoral conduct, sexual deviancy or dependence on alcohol or drugs" (s.2). More important, the sub-categories - severe subnormality and subnormality - were replaced by the terms "severe mental impairment". The definition of these sub-categories is essentially the same as under the 1959 Act, except that the person's arrested or incomplete development of mind must now be associated with "abnormally aggressive or seriously irresponsible behaviour" (s.1). This limits the discretion of a medical practitioner to recommend long-term compulsory admission by requiring 
him to show some behavioural basis indicating aggression or serious irresponsibility. Finally, the Act introduces a new "treatability" test for long-term compulsory admission. It requires, in the case of psychopathic disorder or mental impairment, that "treatment is likely to alleviate or prevent a deterioration in his condition".

\section{Guardianship}

One of the most significant shifts in emphasis toward more limited professional discretion is in the powers of the guardian. The Mental Health Act 1959 granted to the guardian all powers that a father would have over a child under the age of fourteen. These powers are not specified in legislation, but are thought to be considerable, possibly imposing on the ward significant civil disabilities which prevent, for example, marriage or entering into a contract. Some local social services authorities considered that the guardian must exercise "parental powers" in a broad sense and must accept extensive responsibility for the behaviour and protection of the patient. This has been one of the reasons for a sharp decrease in the number of guardianship applications in the last decade.[31]

The Amendment Act introduces an "essential" or "specific" powers approach so that the guardian has power only to require residence in a specified place, attendance for the purpose of medical treatment, occupation, education or training, and access to the patient to be given to a doctor or social worker (s.8). Notwithstanding these powers, reception into guardianship does not require the patient to receive treatment without consent (s.42(1)). Further, guardianship applications can no longer be made in respect of children under the age of sixteen (s.7).

Guardianship is a term which should encompass two distinct concepts: the incompetency of a person to make certain decisions, and the authority delegated to another person to make decisions on behalf of the ward.[32] Incompetency is seldom all inclusive; a mentally disordered person's ability to understand and participate in his social and physical environment will vary over time and under different situations. Guardianship legislation, properly conceived, would limit a person's freedoms and autonomy only to the extent that he is incapable of responsible action and decision-making.[33] Further, legislation should impose positive duties on the guardian to provide assistance and obtain services for the ward, instead of authorising him to exercise compulsory powers. The essential powers approach in the Amendment Act represents a partial recognition of the need to limit the exercise of compulsory powers, although there is significant scope for more creative use of personal guardianship in future mental health legislation.

\section{Tribunal Review}

Mental Health Review Tribunals are the institutional means by which a patient can challenge the substantive justification for his detention. The 
1959 Act severely limited the opportunities where a person could apply for a tribunal; only patients admitted under the long-term provisions of the Act are eligible to apply and generally only during the applicable periods of detention. Further, some $85 \%$ of those eligible to apply do not exercise their entitlement.[34]

The Amendment Act significantly increases the opportunities for tribunal review. It does so by halving the periods of detention (s.12); by providing for automatic referral for those who do not take the initiative to apply (s.40); and by extending the right to apply to patients detained for “assessment" (previously "observation") (s.3).

The Act gives restricted patients detained under sections $60 / 65$ of the 1959 Act the right of access to a tribunal with the power to discharge (s.28 and sch. 1). This represents a fundamental change in philosophy by removing from the Home Secretary the power to determine when, and under what conditions, a patient, who was considered dangerous by the sentencing court, should be discharged. This important reform was forced upon the Government by the decision of the European Court of Human Rights in $X v$. the United Kingdom. The Court ruled that section 65 of the 1959 Act violated Article 5(4) of the Convention because restricted patients were unable to have a binding periodic judicial determination of the substantive justification for their detention.[35] The Court's judgment was referred to frequently in the Parliamentary debates.[36]

\section{Consent to Treatment}

The legal position of the detained patient to refuse treatment under the Mental Health Act 1959 was unclear, notwithstanding the commonly held medico-legal assumption that involuntary admission was intimately associated with a patient's subsequent treatment.[37] The Amendment Act (Part VI) clarifies the position of the detained patient. It is probably the only statute in the recent history of the law of England and Wales which makes comprehensive arrangements for the treatment of patients without consent.

The Act creates a series of formal obstacles in cases where certain treatments are to be administered to detained patients. The consent provisions apply to any patient "liable to be detained", except those admitted under short-term powers or remanded to hospital for report. Several categories of treatment are dealt with differently. First, psychosurgery and other forms of treatment as may be specified by regulations or a code of practice cannot be given unless the patient consents and a second opinion is obtained. A medical practitioner and two other persons appointed by the Mental Health Act Commission must certify in writing that the patient is competent and has consented. The medical practitioner, moreover, must certify in writing that, having regard to the likelihood of the treatment alleviating or preventing a deterioration of the patient's condition, it should be given. Further, before giving a certificate, the 
medical practitioner must consult with two other persons who have been professionally concerned with the patient's treatment, one of whom is a nurse and the other neither a nurse nor a doctor.

These arrangements represent one of the basic departures from traditional common law assumptions contained in the Act. Specific treatments which give rise to special concern cannot be given even with the consent of the patient, unless there is independent verification that the patient is competent to give consent and that the treatment is effective. This departure from the common law principle respecting a voluntary therapeutic relationship between doctor and patient is further undermined by the fact that the provisions requiring consent and a second opinion apply to patients not liable to be detained. This is an instance where departure from traditional legal norms may be justified. This is because of the difficulties of obtaining a voluntary and informed consent from psychiatric patients; the potentially hazardous or irreversible nature of the treatment on patients; and the need to control the psychiatric profession in its use of treatments which may not be fully established.[38]

The second category of treatment applies to the administration of medicine by any means and treatments to be specified in regulations; the regulations are almost certain to include electro-convulsive therapy. These treatments cannot be given unless the patient consents or a second opinion is obtained. The consent must be confirmed by a certification in writing by the responsible medical officer (RMO) or by a medical practitioner appointed by the Mental Health Act Commission. The second opinion must be given by a medical practitioner appointed by the Commission who must certify in writing that the patient is not capable of giving consent or has not consented but, having regard to the likelihood of it alleviating or preventing a deterioration in his condition, the treatment should be given. Before making a certificate the doctor must consult a nurse and another professional (not being a doctor or a nurse) who is professionally concerned with the patient's treatment.

The need for a second opinion does not arise in the case of "administration of drugs by any means" until three months after the drug was first administered. However, the "three months rule" would not apply to treatments listed in regulations or the code of practice.

The Act provides that all other forms of treatment for mental disorder which are not included in the provisions outlined above may be given without the need to obtain a consent or a second opinion. This could conceivably include potentially intrusive forms of treatment such as behaviour modification, physical restraint and seclusion. Much will depend upon the adequacy of the regulations and code of practice which will be prepared by the Secretary of State in consultation with the Mental Health Act Commission.

The Amendment Act provides, for the first time in the history of the law 
of England and Wales, specific authority to impose somatic treatment upon a patient who understands the nature and purpose of the treatment, but expressly withholds consent. It had previously been observed that:

... in psychiatry and law the entire edifice of forcible treatment is erected upon the presumed incompetence of patients to consent to medical procedures. Any other position would be arbitrary; if a patient has the capability reasonably to understand the nature and purpose of treatment there is no more justification for disregarding his own conception of his self interest than there is in the case of any other patient - whether physically or psychiatrically disabled.[39]

The Amendment Act establishes intricately detailed regulation of consent, treatment and second opinions. Consents or certificates under the Act may relate to plans of treatment which may specify a number of different forms of treatment. Where a certificate is given for a plan of treatment it provides authority for the administration of all of the diverse forms of treatment within the plan. The Act upholds the common law right to withdraw consent, but only subject to broad emergency provisions. Urgent treatment can be given without the need for consent or a second opinion. The "urgent treatment" provisions are broadly based and include the right to prevent "a serious deterioration in the patient's condition" or to "alleviate serious suffering". There are exceptions for hazardous or irreversible treatments which are defined tautologically in the Act.

The consent to treatment provisions, on their face, appear to be a triumph of legalism; they are complex and require the doctor to proceed through a number of procedural obstacles prior to the administration of certain treatments. If closely examined, however, the consent provisions represent a return to legal formalism, but do not provide an effective safeguard for the unconsenting patient, except in respect of treatments requiring consent and a second opinion. The form of second opinion is medical with a duty only to consult other professionals. Professional selfregulation is always open to the criticism that it is not sufficiently open, rigorous and dispassionate. The duty to consult other professionals was very much a compromise measure arrived at by the House of Commons Standing Committee. It represented, firstly, an attempt by the Committee to legislate for good practice by requiring doctors to operate on a multidisciplinary basis; secondly, it was viewed as a greater safeguard for the patient to invoke a more widely-based second opinion. The difficulty with the compromise is not only that the role of non-medical professionals is part of a consultation - not a decision-making - process, but also that those professionals are not independent. As part of the therapeutic team at the hospital who originally devised the treatment, they will not be in a position to effectively question their own treatment programme.

In summary, the Amendment Act seeks to protect the rights of patients through the use of formal certifications and detailed procedure reminiscent of the Lunacy Laws. It will not satisfy mental health professionals because of its heavily legalistic quality, emphasising form rather than substance, 
and requiring the detailed observance of technical legal standards and recordings. At the same time it will not provide patients with a meaningful safeguard, firstly, because of the number and extent of exceptions to the principle of self-determination and, secondly, because there will be insufficient confidence in a system which relies essentially upon peer review.

\section{The Mental Health Act Commission}

Since the abolition of the Board of Control in 1959 there has been no body with specific responsibility to examine the use of compulsory powers under mental health legislation.[40] The Secretary of State, however, is now to establish under section 11 of the National Health Service Act 1977 a special health authority to be known as the Mental Health Act Commission (The 1982 Act, s.56). The MHAC will have a general protective function over detained patients. It will have the specific functions of visiting and interviewing patients, having complaints investigated, and appointing medical practitioners and other professionals for giving second opinions under the consent to treatment provisions.

The Commission is potentially important for holding professionals accountable for their decisions. There will, however, be limitations on its effectiveness: it has few statutory powers, for example, to discharge a patient or to enforce its recommendations following the investigation of a complaint; it has only 70 part-time members with the duty to visit and interview detained patients in more than 300 hospitals; it has at present no jurisdiction over informal patients; and it has no power to examine the general conditions or quality of services provided in hospitals.

\section{MAINTAINING THE CIVIL AND SOCIAL STATUS OF PATIENTS}

The final legal approach to contemporary mental health problems is to maintain the civil and social status of those designated as mentally ill or handicapped. Paradoxically, broadly based discrimination is, in part, an inheritance of the Lunacy Laws and other legislation devised in the Victorian era. Such legislation, when examined carefully, is devoted, not to provision of services, but primarily to the withdrawal of certain rights or privileges which are afforded to others in society. Basic societal rights or privileges such as enfranchisement, correspondence, jury service, access to the courts, control of one's own possessions and finance, licences to drive or engage in a profession, and immigration, can often be withdrawn without posing the question - is the individual capable of exercising the right or privilege at issue? The contemporary legal principle is that legislation should not place extra jurisprudential, social or political burdens on those designated as mentally disordered unless these are justified by substantial and reasonable societal objectives.

There follows an examination of two selected reforms in the Amendment Act where Parliament implicitly questioned traditional paternalistic 
attitudes toward mental disorder and deviance. The right of access to the courts and enfranchisement have been chosen as illustrations because of their importance in establishing the civil and social status of any insular minority in society.

\section{Access to the Courts}

Section 141 of the Mental Health Act 1959 placed a significant impediment on any person seeking to bring civil or criminal proceedings against any person carrying out functions in pursuance of the Act. It required the person to obtain leave of the High Court before bringing such proceedings, and leave could not be granted unless there were substantial grounds to show that the person to be proceeded against acted in bad faith or without reasonable care. In many important cases, such as wrongful imprisonment, the Act did not simply impede, but effectively prevented a psychiatric patient from obtaining legal redress because bad faith or lack of reasonable care were not part of the cause of action. In Kynaston's case,[41] for example, a psychiatric patient was placed in the invidious position of not being permitted even to present a claim to the domestic courts that he was a sane person detained in a maximum security hospital without lawful justification.

The origins of section 141 give an indication of the social and jurispridential assumptions upon which it is based. In evidence to the Dillwyn Committee Mr. Maudsley, M.D., expressed the concern that "some years ago there was an action brought against a medical man for illegally signing - an order for detention for a patient ... It appears to me there should be some relief to medical men".[42] Similarly, the Royal Commission on Lunacy and Mental Disorder spoke of a "certification strike" by medical practitioners because of their alleged vulnerability to legal actions by patients.[43] Thus, the historical origin of the withdrawal of a basic right to those designated as mentally ill arose, not because of any evidence that they were incapable of reasonably exercising the right, but because of the perceived need to protect the medical profession.

The earliest precursor to section 141 of the 1959 Act was section 12 of the Lunacy Amendment Act 1889. The terms of section 12 were re-enacted in section 33 of the Lunacy Act 1890 and section 62 of the Mental Deficiency Act 1913. A similar impediment to judicial process was carried over into the Mental Treatment Act 1930. However, throughout this period the way the provision was construed changed almost imperceptibly, until now it has resulted in a rigid judicial attitude toward people suffering from mental distress. In Pountney's case [44] an actual conviction of a nurse for assaulting a patient was overturned on the basis that the patient had no unqualified right to sue. Lord Simon stated that psychiatric patients are "inherently likely to harass those concerned with them by groundless charges and litigation".

The concept that all, or even a substantial majority, of patients in 
psychiatric hospitals would be likely to bring unwarranted litigation unless barred by section 141, contains an antiquated and unsupported notion of how patients are likely to behave. The range of behaviour of people designated as mentally disordered is just as diverse as for any section of the population. The vast majority of people (some, for example, with depression or mental handicap) are admitted to hospital under a set of circumstances which do not justify infringement of their rights. Mere entry into hospital does not justify the conclusion that the patient would be more likely than the population at large to bring vexatious or unnecessary litigation. Indeed an examination of the number of actions brought by psychiatric patients indicates the opposite conclusion - i.e. that the majority of patients are too withdrawn, isolated and unsure to pursue even their genuine legal interests. [45] The Amendment Act reversed the législative and judicial trend of increasing the scope of section 141. At the time the Act was debated in Parliament Kynaston's case (and the related case of Ashingdane $v$. the United Kingdom) were being considered by the European Commission of Human Rights. [46] The European cases illustrated that, far from the original intention, section 141 was effectively protecting public authorities (not doctors or other professional staff) from litigation brought by patients. The European cases featured extensively in the Parliamentary debates in the House of Lords.[47] Indeed a former Conservative Minister of State involved in the passage of the 1959 Act urged the Government to submit to pressure from Strasbourg:

It looks as though both of these cases will be as successful as other recent cases brought to the European Court of Human Rights about other aspects of our law relating to mental health . . . We do not want this kind of proceeding to go on indefinitely - we come out of it badly every time - and it is so obvious on this occasion that we could save ourselves trouble and, indeed, some degree of ignominy.[48]

The Government, despite strong opposition in the House of Lords, did not agree to amendments of section 141 . This resulted in considerable private activity from members of the House of Commons Standing Committee on the Bill and from concerned voluntary bodies. As a result the Government agreed, without recourse to any further Parliamentary debate, to an amendment put forward in Committee which was clearly designed to rectify the injustices apparent in the Strasbourg cases.[49] The Act removes from the scope of section 141 proceedings against the Secretary of State or a health authority; criminal proceedings are now to be brought with the consent of the Director of Public Prosecutions, instead of by leave of the High Court; and the requirement of showing "substantial grounds" for the claim is to be removed (s.60).

\section{Enfranchisement}

In order to vote in the United Kingdom the person's name must appear on the register of electors as a resident of a particular locality. Any place where the elector legitimately resides may be used as an address which qualifies the person for entry onto the register. The single exception is 
found in section 4(3) of the Representation of the People Act 1949 which prevents any "patient" who resides in a hospital maintained for the treatment of mental disorder from using that address for electoral purposes.

The fundamental objection to section $4(3)$ is that it deprives a citizen of the right to vote, not on the basis of individual fitness, but solely on a residential criterion. An informal patient who has a home address can be registered and can either visit a polling station or be treated as an absentee voter. Equally capable patients from the same hospital will be deprived of the vote simply because they have no alternative address. Closer scrutiny of section 4(3) reveals further anomalies. Homeless patients in general or geriatric hospitals are entitled to use the hospital as their place of residence for voting purposes. Accordingly, a patient in a psychiatric unit of a district general hospital is entitled to vote whereas a resident in a psychiatric hospital, possibly with the same psychiatric classification, is not. In effect, the system disenfranchises people who are homeless and who reside in mental illness or mental handicap hospitals, irrespective of their common law capacity to vote.[50]

Two county court cases brought by MIND established the right to vote for residents of mental illness and mental handicap hospitals who could not be regarded as patients within the meaning of section 147 of the 1959 Act.[51] In effect, this would apply only to those who are not considered mentally disordered; since the definition of mental disorder under section 4 of the 1959 Act is so expansive, the county court cases theoretically should enfranchise few residents. Nevertheless, the Government issued circulars following the two county court decisions which probably increased their impact.[52]

The Parliamentary debates placed great emphasis on the anomalies in the law.[53] The objective of the House of Commons Standing Committee - to uphold the legal and social status of patients - was illustrated by Christopher Price, MP:

The Committee agreed that one purpose of the Bill was to give a greater sense of dignity to patients in mental hospitals. That has been our aim throughout. We did not want to erode their rights, personality or dignity unless we had to. Yet there is no better way to erode a citizen's dignity more closely than by telling him that he is disenfranchised, especially when he is perfectly capable of understanding what voting is all about.[54]

The Standing Committee voted by a majority of one to repeal the relevant provisions of section 4(3).[55] The Government came under considerable pressure to reverse the Committee's amendment by Members of Parliament who held marginal constituencies and where there was a sizeable patient population. There was an assumption that enfranchising patients would have a "swamping" effect and would distort election results.[56] The assumption, however, was unfounded; an American study 
showed that patients voted in patterns which accorded exactly with the population at large, including the number of spoilt votes. [57]

The Amendment Act (s.62(2) and sched. 2) contains a compromise which allows a "voluntary mental patient" residing in "mental hospital" on the qualifying date to make an annual declaration which enables him to be registered as an elector in respect of an address outside of the hospital. Such a patient can register to vote at an address where he would be resident if he were not in hospital - e.g. a home or hospital to where he expects to be discharged - or any address (other than a mental hospital) at which he was residing in the United Kingdom. (This need not be the last such address). The declaration must be made without assistance (except assistance necessitated by blindness or other incapacity) and must be attested in the prescribed manner by a member of the hospital staff.[58]

The result, then, is to allow most informal patients to vote, but not to influence the election result in the constituency where the hospital is situated. For long-stay patients the hospital is their home. Enabling such patients to exercise the franchise in another, perhaps distant, constituency means that Members of Parliament and Councillors will not be in a position to concern themselves with the welfare or problems of the constituent, or the adequacy of his surroundings. The elected official to whom the elector should relate is the one representing the locality where the elector lives, and where the services he depends upon are provided. The advantage of allowing substantial numbers of voluntary patients to be included on the electoral register in some local Government wards or Parliamentary constituencies is that it might lead to elected officials becoming more interested and responsive to the interests of those patients.

The new arrangements continue to be anomalous in that they do not allow patients to use mental illness or mental handicap hospitals as a place of residence for voting purposes, but allow patients in other hospitals and nursing homes to do so. Informal patients have had to live in hospital rather than the community, not because their condition requires inhospital treatment, but because successive Governments have failed to provide sufficient aiternative accommodation and support outside the institution. Department of Health and Social Security figures have consistently shown that between one and two thirds of patients enter mental illness and mental handicap hospitals primarily for domiciliary and social reasons. [59] The institution, therefore, has a distinct "hotel" or "asylum" function, providing accommodation for people with no home. The failure to meet publicly stated targets of community-based care should not be compounded by a diminution in the electoral influence of the most disadvantaged and isolated patients who have few other ways of being heard.

The Amendment Act was "drafted to ensure that no voluntary patient loses his vote because he cannot give an address".[60] Nevertheless, for a small number of long-stay patients, there may be no former home in 
existence or which has been accurately recorded on hospital records; such patients also may not be in a position to know where they would reside if discharged.

The provision that the declaration must be completed without assistance represents an implicit capacity test which was intended to replace the general tests if incapacity under common law.[61] However, because the statute is framed as part of the procedures for registration and not as a substantive test of capacity, it is unclear whether a court would construe them as supplanting such common law disabilities or as an addition to them. The requirement of completing a declaration unassisted and with attestation places psychiatric patients at a disadvantage. There is no proscription on other electors obtaining assistance. Assistance to complete postal forms, for example, is provided to elderly or infirm people in the community, nursing homes and general hospitals and to patients on psychiatric wards of district general hospitals. Further, there is no provision in electoral law for a declaration to be attested by another person. It appears inequitable for a capacity test to pertain to a voluntary mental patient but not to any other elector who may need assistance. It is likely that a patient who has lived in hospital for many years will need assistance in completing an electoral registration form. For a patient who has been institutionalised over a long period of time, and who will not have had experience with electoral registration, it is unreasonable to expect him to complete a form without discussion with hospital staff or relatives.

Thomas Szasz observed of the amendment to enfranchise patients that it "simply legitimises psychiatric paternalism: " "giving" mental patients the vote is like "giving" slaves the vote - an Orwellian tragedy of words and deeds".[62] From the perspective of an entitlement philosophy the amendment confers a "right" which is symbolic of an improved social status of patients. The "right", however, has been diluted so that it does not further, even indirectly, a substantial interest of the patient such as liberty or the receipt of services.

\section{Summary and Conclusion}

The "ideology of entitlement" appears to be an ill-conceived philosophy upon which to promote the interests of any socially impoverished group of people. There is a traditional affinity of law and lawyers to more established interests in society and with public protection. There can be few underprivileged people who feel comfortable with the law and who are aware of its use to promote their interests and to meet their social needs. The law is often perceived as concerned more with punishment, together with formal procedural protection against unjustified punishment, than with therapeutic ideals or the protection of morally justified values.

It is important to remain vigilant to any attempt by the legal profession to erect a superstructure of technical procedures or cumbersome legal regulations; nor should the discretion of lawyers and courts be substituted 
for that of mental health professionals on matters of treatment. The modern function of law suggested here does not usurp the function of caring professions. It seeks to alter social perceptions of the mental health services, which should place an emphasis on the person distressed and not on the concerns of society or the profession. Once this principle is accepted it follows that services should be provided as of right, according to the needs of the person and not at the discretion of the professional; a person's consent should be the operative factor and not what others feel would be in the individual's best interests; and the receipt of services should be for the benefit of the person and not to provide an automatic rationale for society to diminish the civil and social status of the individual.

\section{NOTES AND REFERENCES}

[1] K. Jones, A History of the Mental Health Services (1972); L. Blom-Cooper and M. Jefferys, "Foreword" in L. Gostin, A Human Condition (1975; vol. 1); P. Bean, Compulsory Admissions to Mental Hospitals (1980).

[2] K. Jones, op. cit.; K. Jones, "The Limitations of the Legal Approach to Mental Health" (1980) 3 Int' J. Law and Psychiat. 1-15; A. Clare, Psychiatry in Dissent (1980); P. Sedgwick, Psycho Politics (1982).

[3] DHSS, A Review of the Mental Health Act 1959 (1976) paras. 8.3-8.11; L. Gostin and E. Rassaby, Representing the Mentally III and Handicapped: A Guide to Mental Health Review Tribunals (1980).

[4] L. Gostin, A Human Condition (1975, 1977; two vols.). Approximately two-thirds of the provisions in the 1982 Act derive from these MIND publications. Lady Bingley et al., The Times, 20 April 1982; C. Irving, 20 H.C. Debs., col. 712 (22 March 1982); L. Gostin, H.C. Debs., Special Standing Committee Fourth Sitting, cols. 142-165 (29 April 1982).

[5] For a more detailed account of the entitlement philosophy see, L. Gostin, "The Ideology of Entitlement: The Application of Contemporary Legal Approaches to Psychiatry" in Mental Illness: Changes and Trends (1983; ed. P. Bean). For a more detailed explanation of the provisions of the Amendment Act see L. Gostin "A Review of the Mental Health (Amendment) Act", Parts I-III (1982) 132 NLJ 1127-1132, 1151-1155, 1199-1203. The government is introducing a Consolidation Bill in the spring session of Parliament 1983 which will alter the numbering of sections indicated in this article.

[6] K. Jones, op. cit., n. 2, p. 14.

[7] P. Sedgwick, loc. cit.

[8] L. Gostin, "The Law Relating to Mental Handicap in England and Wales" in Tredgold's Mental Retardation (1979; ed. M. Craft); L. Gostin, "Complaints and the National Health Service" (Sept. 1981) Legal Action Group Bulletin 206-209.

[9] The Parliamentary Under-Secretary of State for Health, arguing for the government that a specific after-care amendment was redundant, set out the local authority's responsibilities to provide services. Lord Elton, 427 H.L. Debs., cols. 913-915 (23 February 1982), cols. 1411-1412 (4 March 1982). As regards health authorities, an equivalent duty is encompassed in section 3(1) of the National Health Service Act 1977.

[10] DHSS, Reform of Mental Health Legislation (1981; Cmnd. 8405); The Secretary of State for Social Services, Mr. Norman Fowler, 20 H.C. Debs., cols. 688-695 (22 March 1982).

[11] Baroness Masham, 427 H.L. Debs., cols. 908-909 (23 February 1982), cols. 1401-1404 
(4 March 1982); Baroness Elliot, 427 H.L. Debs., col. 910 (23 February 1982); Lord Avebury, 427 H.L. Debs., col. 915 (23 February 1982); Christopher Price, H.C. Debs., Special Standing Committee Fourteenth Sitting, cols. 552-553 (15 June 1982).

[12] Masham, ibid., col. 1403. See also col. 917.

[13] Lord Redcliffe-Maud, 427 H.L. Debs., col. 1406 (4 March 1982).

[14] Lord Elton, op. cit., n. 9; the Under-Secretary of State for Health and Social Security, Geoffrey Finsberg, H.C. Debs., Special Standing Committee Fourteenth Sitting, cols. 551-552 (15 June 1982); Memorandum from the Association of Directors of Social Services, H.C. Debs., Special Standing Committee Fourth Sitting, col. 177 (29 April 1982).

[15] D. Russell Davis, "Compulsion under Part IV of the Mental Health Act of 1959" (1979) 2 Int'l. J. Law and Psychiat. 169-183; British Association of Social Workers, Mental Health Crisis Services - A New Philosophy (1978).

[16] DHSS, Review of the Mental Health Act 1959 (1978; Cmnd. 7320) para. 2.8. See also discussion of crisis intervention, L. Gostin, H.C. Debs., Special Standing Committee Fourth Sitting, col. 158 (29 April 1982).

[17] Terry Davis, H.C. Debs., Special Standing Committee Twentieth Sitting, cols. 752-758 (24 June 1982); Gwyneth Dunwoody 20 H.C. Debs., cols. 696-700 (22 March 1982).

[18] L. Gostin and E. Rassaby, Representing the Mentally Ill and Handicapped: A Guide to Mental Health Review Tribunals (1980); L. Gostin, "Representing the Mentally Ill" (October 1980) Legal Action Group Bulletin 233-234; L. Gostin, "Statutes of Liberty" (March 16 1982) 13 Social Work Today 14.

[19] Report of the Royal Commission on the Laws Relating to Mental Illness and Mental Deficiency (1957; Cmnd. 169; Lord Percy) paras. 184-188, 265-267.

[20] Lord Renton, 426 H.L. Debs., col. 789 (25 January 1982); Lord Elwyn-Jones, 426 H.L. Debs., cols. 793-794 (25 January 1982); Lord Hooson, 426 H.L. Debs., cols. 794-795 (25 January 1982); Lord Hooson, 427 H.L. Debs., cols., 889-892 (23 February 1982).

[21] Thirteenth Annual Reports of the Law Society and of the Lord Chancellor's Advisory Committee paras. 55-56 (1981).

[22] Collins v. The United Kingdom, application no. 9729/82. The Times 23 February 1982. See L. Gostin, "Human Rights, Judicial Review and the Mentally Disordered Offender" (1982) Crim. L. Rev. 779-793.

[23] Winterwerp v. The Netherlands, Judgment of the European Court of Human Rights, 24 October 1979, paras. 60-61, 101-102.

[24] Judgment of the European Court of Human Rights, 9 October 1979, para. 24.

[25] Lord Elton, 426 H.L. Debs., cols. 790-792 (25 January 1982); Lord Elton, 427 H.L. Debs., cols. 894-895 (23 February 1982). The government defeated the amendment at Committee Stage (Second Day) by 82 votes to 77 . At Report Stage (First Day) the government prevailed by 60 votes to 58 .

[26] Memorandum on behalf of the Lord Chancellor, H.C. Debs., Special Standing Committee Second Sitting, cols. 3-5 (22 April 1982).

[27] Legal Advice and Assistance (Amendment) Regulations 1982, regs. 3-4. The Legal Aid Committee of the Law Society has produced a "Note for Guidance" published in the Law Society Gazette, 24 November 1982.

[28] Memorandum on behalf of the Lord Chancellor, loc. cit., n. 26.

[29] Blom-Cooper and Jefferys, loc. cit., n. 1. 
[30] L. Gostin. "Compulsory Treatment in Psychiatry: Some Reflections on Self-Determination, Patient Competency and Professional Expertise" (1982) 7 Poly. L. Rev. 86-93.

[31] DHSS, op. cit., n. 16, paras. 4.7-4.8.

[32] G. Morris, "The Use of Guardianships to Achieve - or to Avoid - The Least Restrictive Alternative" (1980) 3 Int'l J. Law and Psychiat. 97-115; L. Gostin, The Court of Protection: The Benign Jurisdiction of the Guardianship of the Estate (1983).

[33] L. Gostin, "The Merger of Incompetency and Certification: The Illustration of Unauthorised Medical Contact in the Psychiatric Context" (1979) 2 Int'l J. Law and Psychiat. 127-168.

[34] L. Gostin, A Human Condition, vol. 1 (1975).

[35] $X \mathrm{v}$. The United Kingdom, Judgment given 5 November 1981. See oral submission to the government by the author and Mr. Michael Napier, co-counsel for the applicant, note of the hearing held on 22 June 1981 (morning session); L. Gostin, loc. cit., n. 22.

[36] The Parliamentary Under-Secretary of State, Home Office, Lord Belstead, 426 H.L. Debs., cols. 759-763 (25 January 1982); Lord Kilmarnock, 427 H.L. Debs., cols. 863-864, 874-877 (23 February 1982); Memorandum by the Home Office H.C. Debs., Special Standing Committee Second Sitting, cols. 5-8 (22 April 1982); The Minister of State, Home Department, Patrick Mayhew, H.C. Debs., cols. 9-10 (22 April 1982).

[37] L. Gostin, "Observations on Consent to Treatment and Review of Clinical Judgment in Psychiatry: A Discussion Paper" (1981) 74 J. Roy'l Soc. Med. 742-752; A. Clare, "Consent to Treatment" (1981) $74 \mathrm{~J}$. Roy'l Soc. Med. 787-789.

[38] L. Gostin, "Psychosurgery: A Hazardous and Unestablished Treatment? A Case for the Importation of American Legal Safeguards to Great Britain" (1982) J. Soc. Wel. Law 83-95.

[39] L. Gostin, op. cit., n. 30, p. 87.

[40] Royal Commission, op. cit., n. 19, paras. 778-791. See R. Bluglass, "Towards a New Mental Health Act: Mental Health Commission for England and Wales" (July 1981) Bull. Royal Coll. Psychiat. 130-132; L. Gostin, "The Mental Health Act Commission", (14 May 1982) The Health Services 8-9.

[41] Kynaston v. Secretary of State for the Home Department and Secretary of State for the Department of Health and Social Security (unreported). Court of Appeal (Civ. Div.), 18 February 1981. See L. Gostin, loc. cit., n. 22.

[42] Report from the Select Committee on Lunacy Law (1877; Lord Dillwyn), Minutes of Evidence, para. 4839. See also evidence of Dr. Lush, paras. 1594-1596 (10 April 1877), Mr. Aspland, paras. 4842-4848 (1 May 1877).

[43] Report of the Royal Commission on Lunacy and Mental Disorder (1926; Lord Macmillan).

[44] Pountney v. Griffiths [1975] 2 A11 ER 881.

[45] L. Gostin, A Human Condition, vol. 1, chap. 8 (1975); L. Gostin, "Unimpeded Access to the Courts" (1979) 129 N.L.J. 213.

[46] Kynaston v. The United Kingdom, application no. 9480/81; Ashingdane v. The United Kingdom, application no. 8225/78, admissibility report, 5 February 1982.

[47] Lord Hooson, 426 H.L. Debs., cols. 803-805 (25 January 1982); Lord Wallace of Coslany, 427 H.L. Debs., cols. 917-918 (23 February 1982); Lord Elton, 427 H.L. Debs., cols. 919-920 (23 February 1982).

[48] Lord Renton, 426 H.L. Debs., col. 806 (25 January 1982). 
[49] H.C. Debs., Special Standing Committee Nineteenth Sitting, col. 722 (24 June 1982, morning).

[50] L. Gostin, “A Mental Patient's Right to Vote” (1976) 2 Poly. L. Rev. 17.

[51] Wild and Others v. Electoral Registration Officer for Warrington and Another, County Court for Warrington, 15 June 1976; Smith and Others v. Electoral Registration Officer of Clitheroe Constituency, Blackburn County Court, 16 September 1981.

[52] RPA 261; HN(76) 180.

[53] Lord Kilmarnock, 426 H.L. Debs. , cols. 810-812 (25 January 1982); M. Thomas, H.C. Debs., Special Standing Committee Eighteenth Sitting, cols. 681-685 (22 June 1982. afternoon); D. Ennals, H.C. Debs., Special Standing Committee Eighteenth Sitting, cols. 686-688 (22 June 1982, afternoon).

[54] C. Price, H.C. Debs., Special Standing Committee Eighteenth Sitting, col. 689 (22 June 1982, afternoon).

[55] H.C. Debs., Special Standing Committee Eighteenth Sitting, col. 700 (22 June 1982 , afternoon).

[56] P. Mayhew, 29 H.C. Debs., col. 178 (18 October 1982); Waugh, "Times Out of MIND" (23 October 1982) The Spectator 6.

[57] U.S. Department of Health, Education and Welfare, Office for Handicapped Individuals, Programs for the Handicapped (1976).

[58] P. Mayhew, op. cit., cols. 179-180. Regulations are to be made which will prescribe the manner in which the declaration is to be attested.

[59] DHSS, Mental Handicap: Progress, Problems and Priorities: A Review of Mental Handicap Services in England (1980); L. Gostin, "Mental Handicap Policy in Great Britain: The Advent and Demise of the Institution" (1982) 10 Mental Handicap Journal $39-42$.

[60] Private correspondence from P. Mayhew, Under-Secretary of State at the Home Department, to the author dated 12 October 1982; H.C. Written Answers, cols. 281-282 (25 October 1982).

[61] Ibid.; P. Mayhew, op. cit., col. 179.

[62] T. Szasz, "Lunatic Reform" (4 December 1982) The Spectator 16. 